\title{
Methods of Tree Appraisal: A Review of Their Features and Application Possibilities
}

\author{
M.A. Grande-Ortiz, E. Ayuga-Téllez, and M.L. Contato-Carol
}

\begin{abstract}
Urban trees perform a number of basic functions related to the environment and the welfare of city dwellers (ecological, recreational, psychological), although their benefits are not readily quantifiable. However, in certain situations, it is essential to assign an economic value to the trees. There are currently various methods for valuing the benefits of trees and greenspaces in human settlements, including statistical methods, the travel cost method, contingent valuation, the hedonic pricing method, and integrated methods. However, these methods are not used in official valuations of urban trees; in these cases, appraisal methods are used. The aim of this paper is to study the appraisal methods used for their detailed features and the possibilities of their application. The main conclusion of this review is that there are a number of methods with different types of application. The best method is selected according to tree location, type of land ownership, and the availability of data. Methods with a higher degree of applicability are CTLA, a parametric method of low difficulty, and Contato, a mixed method of medium difficulty. In any case, it is advisable to increase efforts to objectify the correction index in the case of parametric and mixed methods.

Key Words. Appraisal; Parametric Indexes; Urban Trees; Valuation.
\end{abstract}

A tree provides many benefits to the urban dweller, both environmental (Jim and Chen 2009) and psychological (Sugiyama et al. 2008; Lafortezza et al. 2009). The presence of trees, whether grouped together in greenspaces or lining streets, is considered essential in improving the quality of life and well-being of city dwellers (Table 1).

In cities, trees have been considered to fulfil a primarily ornamental purpose; however, there is no doubt that they also perform other equally important functions, such as their use for recreation (Gundersen et al. 2006), their role as a link between man and nature (Dwyer 1995; Aldous 2007), and their contribution to the general well-being of the city's residents (Dwyer et al. 2000; O'Brien 2005). Moreover, numerous works have demonstrated the role of urban trees in improving the environment (Nowak 2006) (Table 2).

Trees can enhance environments where people show a positive trend in their willingness to pay more for goods and services (Luttik 2000; Wolf 2004; Jim and Chen 2006; Wolf 2009a; Wolf 2009b; Joye et al. 2010). However, all these benefits of urban trees are not readily quantifiable.

Recent studies show an increase in public concern over urban trees (Escobedo et al. 2006; Zhang et al. 2007; Kirnbauera et al. 2009; UEA 2009). Nevertheless, the value of trees to urbanites is generally underestimated (Dwyer et al. 1992), and it currently only becomes necessary to establish the economic value of a tree when:

* Legal regulations need to be applied for updating rates, taxes, or re-estimating land value (Schmied and Pillmann 2003).

* There has been damage to the trees: wounds inflicted by third parties, disasters, floods, storms, or damages caused by the installation and maintenance of public service networks (Jim 2003).

* Jobs need to be done involving the planning and management of work on public trees, financial analysis, or updating of public assets, inventories, and cataloging (Miller 1997).

The experience of these benefits by any single person does not exclude others from experiencing similar benefits, both immediately and indefinitely (Wolf 2005). In this regard, authors such as Fabbri (1989), Miller (1997), Caballer (1999), and Nowak et al. (2002) indicate the difficulties encountered when attempting to set a value on trees in a city. They maintain that this assessment has to be based on the various functions provided by the tree throughout its life.

\section{METHODS TO EVALUATE THE BENEFITS OF TREES AND GREENSPACES}

There are many methods to valuate the benefits of trees and greenspaces in human settlements, including statistical methods, the travel cost method, contingent valuation, the hedonic pricing method, and integrated methods.

Statistical methods (multiple regressions) are used to relate the value of the property to urban trees (Anderson and Cordell 1988; Dombrow et al. 2000; Luttik 2000; Sander et al. 2010). The basic principle of these methods is the statistical probing of the association between green features and property value (Jim 2006). These methods are not easily generalizable and require a large amount of data to replicate the model in another city. 
The travel cost method estimates the value of recreational benefits generated by ecosystems. In this case, the value of the site is reflected in how much people are willing to pay to get there (Dwyer et al. 1983; Willis and Garrod 1991; Berg- ing and Price 1994; McKean et al. 1995; Garrod and Willis 1997; Zawacki et al. 2000; Parsons 2003; Iamtrakul et al. 2005; Delang and Ling 2008). Many people, including jurists, policy makers, economists, and others, do not accept the results of this method

Table 1. The social benefits of urban trees.

\begin{tabular}{|c|c|c|}
\hline Contribution & Description & References \\
\hline Positively influence & $\begin{array}{l}\text { Trees can positively influence people's feelings, } \\
\text { attitudes, moods, and behaviors. }\end{array}$ & $\begin{array}{l}\text { Chang (2008); Kaplan } \\
\text { and Kaplan (2009) }\end{array}$ \\
\hline Medical benefits & $\begin{array}{l}\text { Trees help shorten hospital stays and reduce the } \\
\text { level of medication taken by post-operative } \\
\text { patients. They are beneficial to one's health in } \\
\text { other, indirect ways. }\end{array}$ & $\begin{array}{l}\text { Ulrich (1984); Ulrich } \\
\text { (1986); Heisler and Grant } \\
\text { (2000); Taylor et al. } \\
\text { (2001); Powe and Willis } \\
\text { (2002); Frumkin (2003) }\end{array}$ \\
\hline Mental benefits & $\begin{array}{l}\text { Trees and vegetation can have a strong relaxing } \\
\text { effect, reduce the mental fatigue of the urban } \\
\text { resident, and the Attention Restoration Theory } \\
\text { provides an analysis of the kinds of experiences } \\
\text { that lead to recovery from such fatigue. Trees } \\
\text { create an environment that is more comfortable } \\
\text { to work in, and raises the level of productivity. }\end{array}$ & $\begin{array}{l}\text { Ulrich (1981); Ulrich } \\
\text { (1986); Kaplan and } \\
\text { Kaplan (1989); Hull } \\
\text { (1992b); Kaplan (1995a); } \\
\text { Kaplan (1995b); } \\
\text { Lewis (1997) }\end{array}$ \\
\hline Social interaction & $\begin{array}{l}\text { Trees attract a person to outdoor public spaces, } \\
\text { which improves opportunities for social } \\
\text { interaction. Although vegetation has been linked } \\
\text { to fear of crime and crime in a number of settings. }\end{array}$ & $\begin{array}{l}\text { Ulrich (1986); Hull } \\
\text { (1992a); Coley (1997); } \\
\text { Lewis (1997); Kweon } \\
\text { et al. (1998); Kuo and } \\
\text { Sullivan (2001); Troy } \\
\text { and Grove (2008) }\end{array}$ \\
\hline Economics benefits & $\begin{array}{l}\text { Trees provide a number of economic benefits } \\
\text { through energy savings. Energy benefits may be } \\
\text { partially offset by certain problems. Urban trees } \\
\text { also provide economic benefits other than } \\
\text { those previously mentioned. }\end{array}$ & $\begin{array}{l}\text { Powell (1993); } \\
\text { McPherson (1995); } \\
\text { Dwyer et al. (1992); } \\
\text { McPherson and Rowntree } \\
\text { (1993); McPherson et al. } \\
\text { (1999b); Sherrill (2003); } \\
\text { McPherson and Muchnick } \\
\text { (2005); McPherson et al. } \\
\text { (2005); Bratkovich } \\
\text { (2008); Donovan and } \\
\text { Butry (2009) }\end{array}$ \\
\hline
\end{tabular}

Table 2. The environmental benefits of urban trees.

\begin{tabular}{|c|c|c|}
\hline Contribution & Description & References \\
\hline Climate control & $\begin{array}{l}\text { Trees lower temperatures by shading surfaces, } \\
\text { dissipating heat through evaporation, and controlling } \\
\text { the air movement responsible for advective heat. }\end{array}$ & $\begin{array}{l}\text { Oke (1980); Dwyer et al. } \\
\text { (1992); Nowak and } \\
\text { McPherson (1993); } \\
\text { Kjelgren and Montague } \\
\text { (1998); Montague and } \\
\text { Kjelgren (2004) }\end{array}$ \\
\hline Soil and water quality & $\begin{array}{l}\text { In the case of water, trees help control stormwater, } \\
\text { raise water quality, and help slow erosion. }\end{array}$ & $\begin{array}{l}\text { Huang et al. (1992); } \\
\text { McFarland (1994); Dwyer } \\
\text { (1995); Bartensa et al. } \\
\text { (2008) }\end{array}$ \\
\hline Air quality & $\begin{array}{l}\text { As trees reduce summertime temperatures, they also } \\
\text { help raise the quality of air in a city. Trees serve as } \\
\text { physical barriers to air-carrying pollutants and through } \\
\text { the sequestration of carbon, help reduce the } \\
\text { greenhouse effect. Through the rustling of leaves, trees } \\
\text { mask unwanted noises and absorb sound. Trees also } \\
\text { modify humidity. }\end{array}$ & $\begin{array}{l}\text { Pesson (1978); Huang et al. } \\
\text { (1987); Oke (1989); Smith } \\
\text { (1990); CEPAL (1991); } \\
\text { Dwyer et al. (1992); } \\
\text { McFarland (1994); Moretón } \\
\text { (1996); Jo (2001); Nowak and } \\
\text { Crane (2002); Codina and } \\
\text { Barón (2003); Fang and Ling } \\
\text { (2003); Nowak et al. (2004); } \\
\text { Bucur (2006); Nowak et al. } \\
\text { (2006a); Nowak et al. (2006b) }\end{array}$ \\
\hline
\end{tabular}


for obtaining the monetary value of an individual tree. Various papers discussing this issue show the divergence of views (De Groot et al. 2002; Contato 2004; Babier and Heal 2006; McComb et al. 2006; Heal 2007; Donovan and Bruty 2008).

The contingent valuation method involves directly asking people, in a survey, how much they would be willing to pay for specific environmental services and is the most widely used method for estimating non-use values (Schulze et al. 1983; Morey et al. 1991; Xu et al. 2003; Jim and Chen 2006a; Vesely 2007; Zhu et al. 2007; Bernath and Roschewitz 2008; Chen and Jim 2008; Lo and Jim 2010; Becker and Freeman 2010). Most urban trees are on public lands, thus making this method difficult to use for assessing urban trees, as local governments do not often have staff for surveying.

The hedonic pricing method estimates the value of environmental amenities that affect the prices of marketed goods. The method is based on the assumption that people value the characteristics of a good rather than the good itself. Prices will therefore reflect the value of a set of characteristics (including environmental characteristics) that people consider important when purchasing the good (Morales 1980; More et al. 1988; Tyrväinen 1997; Tyrväinen and Miettinen 2000; Laverne and Winson-Geideman 2003; Price 2003; Morancho 2003; Jim and Chen 2006b; Wolfe 2007; Sander et al. 2010). This method requires the intermediary of house prices to estimate tree value. If the trees are widely scattered in the city, a large amount of data may be required, possibly making this approach impractical.

Integrated methods employing remote sensing, computer modeling, and computation techniques make it possible to assess the aggregate benefits of the tree cover of a city, but are not suitable for individual tree assessment (Jim 2006).

These methods are not used in the official valuation of urban trees in administrative regulations. In these cases, the valuations are based on tree appraisal methods, as they allow the monetary value of an urban tree to be determined. The objective of the present review is to study these appraisal methods.

\section{APPRAISAL METHODS}

The different methodologies have been classified into three groups (Espluga 1989): multiplicative or parametric methods, economic or capitalization methods, and mixed methods.

Using multiplicative or parametric methods, the value is determined by the equation:

$$
\text { Value }=f\left(\mathrm{x}_{1}, \mathrm{x}_{2}, \mathrm{x}_{3}, \mathrm{x}_{4}, \ldots \ldots, \mathrm{x}_{\mathrm{n}}\right)
$$

where $\mathrm{x}_{1}, \mathrm{x}_{2}, \ldots, \mathrm{x}_{\mathrm{n}}$, are the variables of type, aesthetic appeal, location, historical significance, etc. In these methods, $t$ (age of the tree) is another variable of the valuation equation.

Economic or capitalization methods are based on the application of different procedures for evaluating investments. They distinguish between objective and subjective criteria, which are combined in the previous group. They make it possible to set a monetary value for a living element via the following equation:

[2] Value $=f(\mathrm{t})$

where $t$ is the age of the tree.
Mixed methods are based on a system that combines capitalization and parametric indices. The value formula is:

$$
\text { Value }=f\left(\mathrm{t} ; \mathrm{x}_{1}, \ldots, \mathrm{x}_{\mathrm{n}}\right)
$$

where $\mathrm{t}$ is the age of the tree and $\mathrm{x}_{1}, \ldots, \mathrm{x}_{\mathrm{n}}$, are the variables of type, aesthetic appeal, location, etc. If the initial value is obtained by means of a capitalization meth$\mathrm{od}, \mathrm{t}$ is included in the equation. If the initial value is obtained by a parametric method, $t$ must be parameterized.

\section{Multiplicative or Parametric Methods}

The Tedesco method (Bernatzky 1978) uses the following formula to calculate the value of a tree:

$$
\text { Value }=\mathrm{Vb} \times \mathrm{BA} \times \mathrm{S} \times \mathrm{E} \times \mathrm{I} \times \mathrm{T} \times \mathrm{R}
$$

where $\mathrm{Vb}$ is a value of market price for tree per $\mathrm{cm}^{2}$ of basal area, BA is the section of the basal area, $\mathrm{S}$ is a variable defining the location (open country 1.3 , country 1.5 , forest 1.8 , city 2, downtown 3), and $\mathrm{E}$ represents the condition of the tree on a descending scale from 1 for completely healthy, to 0 for a very ill and weakened specimen. I, an index, reflects the tree's environmental compatibility on a descending scale, from 1 for completely compatible to 0.1 for not compatible, $\mathrm{T}$ is an index that reflects the ratio between life expectancy and age of tree, and $\mathrm{R}$ is the percentage reduction in value due to damage to the tree.

The Swiss method (Ferraris 1984) takes into consideration four basic indices: species (E), state of health and aesthetic value (B), location (U), and size (D). These variables are separated qualitatively to avoid errors of judgment. This method also evaluates damage to trees, including damage that does not involve the total loss of the tree. The method makes use of the following formula:

$$
\text { Value }=\mathrm{E} \times \mathrm{B} \times \mathrm{U} \times \mathrm{D}
$$

The French method (Ferraris 1984) establishes an index related to the cultivation care $(\mathrm{T})$ required for the maintenance of the specimen. Ferraris (1984) reviewed the Swiss methodology and adapted it to include $\mathrm{T}$ in the valuation expression in order to fix a monetary value for trees in private parks and gardens in France. This method attempts to define the most likely cost of replacement. The value is obtained via the use of four indices: a species index (E), an index of health and aesthetic value (B), a location index (L), and a size index (D) (with values determined according to the ranges of the normal circumference). The following expression is used for tree valuation:

$$
\text { Value }=\mathrm{E} \times \mathrm{B} \times \mathrm{L} \times \mathrm{D} \times \mathrm{T}
$$

The Italian method (Fabbri 1989) uses the following formula to calculate the value of a tree:

$$
\text { Value }=\mathrm{P} \times \mathrm{I} \times \mathrm{S} \times \mathrm{C}
$$

This method takes into account the base price of the same species in a nursery $(\mathrm{P})$; an index (I) reflecting the tree's state of health and appearance on a scale of 1 to 10; a location index (S) with values of between 6 and 10, according to whether the 
tree is located in the city or in a rural area; and finally, a factor indicating the size $(\mathrm{C})$, with values from 1 to 55 for normal circumferences of between 30 and $900 \mathrm{~cm}$ respectively.

The North American method (CTLA 1992; CTLA 2000) gave rise to the idea of a "base value" as an expression of the unit price of a section of trunk, and considers the maximum value of a tree to be the product of this base value multiplied by the area of the section of the trunk. Corrector indices (species, condition, and location) maintain or reduce this value, but never increase it.

[8] Value $=\left[\right.$ trunk area $\left(\mathrm{cm}^{2}\right) \times$ basic price $\left.\mathrm{cm}^{2}\right] \times$ species $\times$ condition $\times$ location

The North American method only considers the utilitarian aspect of trees-initially the value of their wood-but in recent years tree value has also been estimated in terms of energy savings, air pollution, and other environmental functions. There is an adaptation of this method in the UK known as CAVAT (Neilan 2008). CAVAT can increase, decrease, or cancel the tree's base value by the corrector index. This method has software that enables automatic calculation of value (CAVAT 2012).

The Finnish method (Caballer 1999) uses a base value for each genus and species, established for each square centimeter of a section of trunk taken $1 \mathrm{~m}$ above the ground. The value of any individual tree is then found by multiplying its cross sectional area at this height by this base value. This is then corrected using a location index (according to whether the tree is in the city or in the country; the value of a city tree is always increased by this step) and a discount parameter based on the specimen's state of health and conservation. The final value is therefore expressed as:

$$
\text { Value }=\mathrm{S} \times \mathrm{P} \times \mathrm{L} \times \mathrm{E}
$$

where $\mathrm{S}$ is the section of the trunk, $\mathrm{P}$ is a value established and tabulated per $\mathrm{cm}^{2}$ of section (which varies according to species), $\mathrm{L}$ is a variable defining the location (open country 1.3 , forest 1.8 , city 2 ), and $\mathrm{E}$ represents the condition of the tree on a descending scale, from 1 for completely healthy to 0.2 for a very ill and weakened specimen.

The formulaic expert method (FEM) (Jim 2006) selects six primary criteria (dimension, species, tree, condition, location, and outstanding consideration) branched in 45 secondary criteria. Each primary criteria is standardized to carry equal weight (maximum aggregate scored is 100) and are then all added together. The tree's monetary value is the result of multiplying the aggregate score of a tree by a monetary assignment factor (MAF). This factor is derived from the three-year average sale price per $\mathrm{m}^{2}$ of medium-sized residential flats. The expression for valuing a tree is:

$$
\text { Value }=(\mathrm{D}+\mathrm{S}+\mathrm{T}+\mathrm{C}+\mathrm{L}+\mathrm{O}) \times(100 / 135) \times \mathrm{MAF}
$$

The scores are computed using additive of secondary value. The secondary values are obtained by selecting from a multiple-choice list of options.

$\mathrm{D}$ is the score for dimension of the trees and is calculated by adding the scores associated with height, crown, trunk, and relative size (maximum value 25 ). $\mathrm{S}$ is the score for the species, including aesthetic value and rarity (maximum value 15). $\mathrm{T}$ is the score for tree specimen and includes the quality of the tree structure and its service as habitat (maximum value 20). C is the score for condition and includes the symptoms of pests and diseases, the scores of condition of the trunk, branches, foliage, and roots (maximum value 25). $\mathrm{L}$ is the score for location and includes abundance, suitability, danger, environment, and environmental benefits (maximum value 20). O is the score for outstanding characteristics and is calculated by adding the score of outstanding features, such as size, botanical interest, or historical association (maximum value 25).

\section{Capitalization Methods}

Capitalization methods evaluate trees by applying indexes, matrix tables, and other simplified forms, and are aimed at making calculations easier for people who are not necessarily experts in the subject. Multiplicative methods do however include the age of the tree as a basic variable, as measured by the size and life-expectancy indexes. The interest rates are the rate of growth of the tree and the accumulated average annual growth rates are distributed in different ways throughout the life of a tree.

There are two basic methods of capitalization: value based on the replacement costs and value based on maintenance costs (Caballer 1999).

The equation used as the basis for replacement cost methods is:

[11] Value $=\mathrm{P}_{\mathrm{r}}+\left(\mathrm{C}_{\mathrm{m}} \times \mathrm{k}\right)+\mathrm{C}_{\mathrm{r}}$

where $\mathrm{P}_{r}$ is the market price of the tree, $\mathrm{C}_{m}$ is the cost of annual maintenance, $\mathrm{C}_{\mathrm{r}}$ is the cost of remov$\mathrm{al}$, and $\mathrm{k}$ is the factor determined by the age of the tree.

The equation used as the basis for maintenance cost methods is:

$$
\text { Value }=(1+\mathrm{i})^{\mathrm{t}-\mathrm{t}_{0}}\left(\mathrm{P}_{\mathrm{r}}+\mathrm{C}_{\mathrm{t}}\right) / \mathrm{P}
$$

where $\mathrm{i}$ is interest rate, $\mathrm{t}-\mathrm{t}_{0}$ is the number of years during which maintenance tasks are performed, $\mathrm{P}_{\mathrm{r}}$ is the market price, $\mathrm{C}_{\mathrm{t}}$ is the planting costs, and $\mathrm{P}$ is the probability of rooting.

\section{Mixed Methods}

The ICONA method (López Arce 1975) was proposed for calculating compensation in the case of loss of ornamental trees. It uses six indices, which when multiplied with each other, give the final value of the tree.

The species and varieties are classified into eight types, and each of these is assigned a particular coefficient (A). This classification uses as a reference the sales price in the respective nurseries, based on the hypothesis that this price accurately reflects the degree of difficulty in reproducing and growing a particular tree species.

The index for aesthetic and functional value and health (B) establishes four values, ranging from 1 for evidently diseased or severely mutilated specimens, to 10 for outstanding, healthy and vigorous trees. The authors' proposal is noteworthy for the distinction it makes between trees planted in groups or arranged in rows.

The method includes a double-entry table for the location index $(C)$ with a combination of elements that provides nine different locations. Values are assigned according to the size of the city measured by the number of inhabitants, and to the tree's visual surroundings (from rural to urban or with special significance).

It also proposes a rarity index (D). The number of trees of a particular species in an area is registered on a scale 
of 1 to 10 , with 1 representing abundant species and 10 representing species that are rare or unique in that area.

The method only has two classifications of a tree's singularity (E): either the tree has a certain uniqueness value (e.g., historical significance) or it is of no cultural interest at all. In the first case the value of the specimen is doubled.

The age index (F) is calculated by means of an age/diameter ratio, expressed as $\mathrm{e}^{2} / \mathrm{d}$, where $\mathrm{e}$ is the age and $\mathrm{d}$ is the normal diameter at breast height. The reason the age is squared is to make the evaluation reflect the fact that the maintenance expenses at advanced ages are much greater.

The final value of a specimen is expressed as follows:

[13] Value $=\mathrm{A} \times \mathrm{B} \times \mathrm{C} \times \mathrm{D} \times \mathrm{E} \times \mathrm{F}$

The Norma Granada method (AEPJP 1990; AEPJP 1999; AEPJP 2007 ) is another mixed method. In early versions of this method (AEPJP 1990; AEPJP 1999), the basic value was obtained for each species in a regression model based on tree age. After its latest revision, the method uses the following expression for valuing a tree:

[14] $\quad$ Value $=(\mathrm{Bv} \times$ Els $)(1+$ Ele $)$

where $\mathrm{Bv}$ is the base value obtained for each species in a regression model based on circumference $(1 \mathrm{~m}$ from the ground), Els is the value for health and photosynthetic activity, Ele is extrinsic factors (such as aesthetic appeal and function, representativity and rarity value, location, and other exceptional factors). A comprehensive collection of data on the tree to be appraised is required in order to obtain these values.

The New Zealand method (standard tree evaluation method, STEM) is one of the most widely used. The method (Watson 2002) uses a point system to rate 20 tree attributes in three general categories of condition, amenity, and notable (special merit) qualities. The point total is then multiplied by the wholesale cost of a five-year-old tree (no indication of species specificity). To this is added the wholesale cost of planting the tree and the cost of maintaining the tree until it reaches the same age as the tree that was lost. Finally, the figure is multiplied by a factor to convert from wholesale to retail (doubling suggested).

[15] Value $=[$ total points $(540$ possible $) \times$ wholesale cost + planting cost + maintenance cost $] \times$ retail conversion factor $(2$ suggested)

The Contato method (Contato 2004) proposes the application of a system that combines capitalization and parametric indices. The valuation formula is the following:

$$
\text { Value of tree }=\mathrm{Bv} \times \mathrm{SI} \times \mathrm{CI} \times \mathrm{IAF} \times \mathrm{LI}
$$

$$
\mathrm{Bv}=\mathrm{Uv} \times \mathrm{ac}
$$

where Uv is the unit value of tree cover expressed in $\$ / \mathrm{m}^{2}$, according to the group to which the species to be valued belongs. The area of the canopy (tree cover), ac, is expressed in $\mathrm{m}^{2}$ of the specimen to be valued. This can be calculated in the field, when on-site measurement of the diameter of canopy is possible. If this is not possible, it is subtracted from the diameter-area of the canopy regression curves established for each species grouping. $\mathrm{Bv}$ is the base value of the tree. Indicated as the product of the Uv of cover, according to the group to which it belongs and its ac. SI is the species index (ranges from 0.6 to 1.2 ). $\mathrm{CI}$ is the index of condition or appearance (values of 0.1 or 2). IAF is the index of aesthetic and functional value (with values of $1,1.25$, and 1.5 ). LI is the index of location or situation (with values of 1, 1.25, and 1.5).

The base value of each tree is calculated from its age, using the capitalization formula, is as follows:

[18] $\mathrm{Uv}=\left(\frac{\mathrm{NP}+\mathrm{PC}+\mathrm{CPS}}{\alpha}\right)(1+\mathrm{i})^{\mathrm{n}}+\operatorname{AMIC}_{\mathrm{j}}(1+\mathrm{i})^{\mathrm{n}-\mathrm{j}}+\mathrm{PEC}_{\mathrm{q}}(1+\mathrm{i})^{\mathrm{n}-\mathrm{q}}$ where NP is nursery price; PC is planting costs; CPS is cost of planting supplies; $\alpha$ is the percentage of trees that become established, expressed as annual planting yield; $n$ is tree age at the time of evaluation; AMIC is annual maintenance costs over $\mathrm{j}$ years;

\begin{tabular}{|c|c|c|c|c|c|c|c|c|c|c|c|}
\hline \multirow[t]{2}{*}{ Methodology } & \multirow[t]{2}{*}{ Method } & \multicolumn{4}{|c|}{ Index } & \multicolumn{3}{|c|}{ Variable } & \multicolumn{3}{|c|}{ Monetary value } \\
\hline & & Species & $\begin{array}{l}\text { State of } \\
\text { health / } \\
\text { aesthetic }\end{array}$ & Location & Others & Age & Trunk & Crown & Cost & $\begin{array}{l}\text { Interest } \\
\text { rate }\end{array}$ & Price \\
\hline \multirow[t]{6}{*}{ Parametric } & Tedesco & ok & ok & ok & ok & & basal area & & & & market \\
\hline & Swiss & ok & ok & ok & & & size & & & & \\
\hline & French & ok & ok & ok & & & circum & & replace & & \\
\hline & Italian & & ok & ok & & & circum & & & & nursery \\
\hline & Finnish & ok & ok & ok & & & area & & & & \\
\hline & FEM & $\mathrm{ok}$ & ok & ok & ok & ok & height, DBH & width & & & market \\
\hline \multirow[t]{5}{*}{ Mixed } & ICONA & ok & ok & ok & ok & ok & $\mathrm{DBH}$ & & & & nursery \\
\hline & Norma & ok & ok & ok & ok & & circum & & & & \\
\hline & Granada & & & & & & & & & & \\
\hline & STEM & & ok & & ok & ok & & & plant and & & \\
\hline & Contato & ok & ok & ok & ok & ok & & area & $\begin{array}{l}\text { maintenance } \\
\text { plant and } \\
\text { maintenance }\end{array}$ & ok & nursery \\
\hline Capitalization & Maintenance & ok & & & & ok & & & plant & ok & market \\
\hline
\end{tabular}

Table 3. Summary of methods for the evaluation of urban trees.

Notes: circum $=$ circumference 
Table 4. Characteristics of methods for the evaluation of urban trees.

\begin{tabular}{|c|c|c|c|c|c|c|c|}
\hline \multirow[b]{2}{*}{ Methodology } & \multirow[b]{2}{*}{ Method } & \multicolumn{3}{|c|}{ Index } & \multicolumn{2}{|c|}{ Variable } & \multirow{2}{*}{$\begin{array}{l}\text { Predominant factors } \\
\text { in the assessment }\end{array}$} \\
\hline & & Subjective & Objective & Integration & Direct & Indirect & \\
\hline \multirow{7}{*}{ Parametric } & Tedesco & $\mathrm{Sp}, \mathrm{H} \& \mathrm{~A}, \mathrm{O}$ & $\mathrm{L}$ & multiplicative & & area & $\mathrm{L}, \mathrm{H} \& \mathrm{~A}$ \\
\hline & Swiss & Sp, H\&A, O & $\mathrm{L}$ & multiplicative & & size & circum \\
\hline & French & Sp, H\&A, O & $\mathrm{L}$ & multiplicative & & circum & circum \\
\hline & Italian & $\mathrm{Sp}, \mathrm{H} \& \mathrm{~A}, \mathrm{O}$ & $\mathrm{L}$ & multiplicative & & circum & circum \\
\hline & CTLA & $\mathrm{Sp}, \mathrm{H} \& \mathrm{~A}, \mathrm{~L}$ & & multiplicative & & area & $\mathrm{H} \& \mathrm{~A}$ \\
\hline & Finnish & $\mathrm{Sp}, \mathrm{H} \& \mathrm{~A}, \mathrm{O}$ & $\mathrm{L}$ & multiplicative & & circum & circum \\
\hline & FEM & Sp, H\&A, L, O & & summative & & $\begin{array}{l}\text { age, circum, } \\
\text { height, crown }\end{array}$ & size, $\mathrm{H} \& \mathrm{~A}, \mathrm{O}$ \\
\hline \multirow[t]{4}{*}{ Mixed } & ICONA & $\mathrm{Sp}, \mathrm{H} \& \mathrm{~A}, \mathrm{~L}, \mathrm{O}$ & & multiplicative & size of trunk & age & age \\
\hline & Norma Granada & Sp, H\&A, L, O & & multiplicative & & age & H\&A \\
\hline & STEM & $\mathrm{Sp}, \mathrm{H} \& \mathrm{~A}, \mathrm{~L}, \mathrm{O}$ & & summative & & age & age \\
\hline & Contato & $\mathrm{Sp}, \mathrm{H} \& \mathrm{~A}, \mathrm{O}$ & $\mathrm{L}$ & multiplicative & area of crown & age & $\mathrm{H} \& \mathrm{~A}$ \\
\hline \multirow[t]{2}{*}{ Capitalization } & Removal & & & & & age & age \\
\hline & Maintenance & & $\mathrm{Sp}$ & & & age & age \\
\hline
\end{tabular}

Notes: $\mathrm{Sp}=$ species; $\mathrm{H} \& \mathrm{~A}=$ state of health and aesthetic value; $\mathrm{L}=$ location; $\mathrm{O}=$ others index; circum = circumference

$\mathrm{j}$ represents the number of years during which maintenance tasks are performed for each of the specimens planted; PEC is possible extra costs; $\mathrm{q}$ is a particular year; and $\mathrm{i}$ is the interest rate.

Table 3 summarizes all of the methods reviewed. For each method, the table includes corrector indices (index); measures taken in the tree (variable), both to obtain the basic value of the tree and to determine the corrector index related to size; and the data used in the valuation for estimating costs and benefits (price).

Table 4 shows the main features of the revised methods: the type of indices (subjective or objective), the method of integrating the indices (multiplicative or additive), the variable used to determine the basic value of the tree (directly or indirectly), and the main factors in the assessment.

\section{DISCUSSION AND CONCLUSIONS}

All the methods value differently. Even for the same method and tree, appraisers obtain different valuation of different orders of magnitude (Watson 2002; Contato-Carol et al. 2008; Ponce-Donoso et al. 2009).

The multiplicative or parametric methods define and quantify one, two or more physical, explanatory and objective variables and combine these with other, more subjective, difficult-tomeasure variables (e.g., aesthetic appeal, location, historical significance) related to the presence of trees in cities (Price 2003).

The capitalization methods are proposed by economists. They consider the tree to be the starting capital that will produce an income or profit over a period of time. Economists do not agree as to which economic reference value should be used to formulate this econometric evaluation (Caballer 1999; Contato 2004).

Parametric and mixed methods consider the location of the tree to be fundamental. The nearer it is to the city center, the higher its value (in these places the effects of urban stress on the plant are greater and the trees are costlier to maintain). The districts with a greater historical or cultural value are usually located in these areas.

Most methods use a subjective index (Table 4). The location index is obtained objectively in a higher number of methods, but is not very discriminating. For example, in the Swiss method, the location index takes values as large groups such as city centre $(L=10)$, peri-urban $(L=8)$ and rural area $(L=6)$. In recent studies, efforts have been made to objectify this index depending on the density of population (Neilan 2008) and according to the relationship between population density and woodland (Ayuga-Téllez et al. 2011).
To overcome the difficulties this poses with regard to value, the proposed index should be as objective as possible. This requires making detailed studies of numerical variables that determine the characteristics of the tree and its surroundings. A univocal relationship between indices and numerical variables can be obtained in this way (Ayuga-Téllez et al. 2011).

The integration of the indices is generally multiplicative, resulting in a greater increase in the differences between assessments made by different appraisers (Watson 2002). It would therefore be desirable to increase the use of additive methods.

Only the ICONA (López Arce 1975) and Contato (Contato 2004) methods used variables measured on the tree. Most variables used parametric methods estimated from other measurements by simple expressions. Capitalization and mixed methods use tree age as a variable, estimated from statistical data (except when the exact date of planting is known). To overcome this disadvantage, the authors recommend that managers of public spaces encourage the recording and safeguarding of this variable for all trees.

The predominant factors in the valuation methods reviewed (Table 4) are of three types, and relate to size, age, and the health-related and aesthetic value of the tree. Age is not decisive in parametric methods. Size is not determining in mixed and capitalization methods.

The methods reviewed do not consider the award of zero value to a tree, even when it is in danger of falling and poses a risk to property and people, when it is located in an inappropriate place, or when it no longer has any functional value. The CTLA and Contato methods assign a value of zero in some cases.

The most suitable uses of each method reviewed depend on the main objective, the location of the trees, the type of land ownership, and the difficulty of the valuation procedure used (Table 5). Three main objectives are established: legal claims, damage assessment, and investment value. These objectives influence the use and purpose of the different types of appraisal. Definitions collected by various authors (Swiecki and Bernhardt 2001; Konijnendijk 2003; Konijnendijk et al. 2006) have been used to establish the types of location, which are as follows: trees lining streets in towns and cities, and roadside trees (TS); parks and gardens within city boundaries (P\&G); forests in urban areas or around towns and cities for the purpose of providing amenities for the population (FA); and special trees (HT) for individual trees that may be considered important community resources due to their unique or noteworthy characteris- 
Table 5. Most suitable applications for each method

\begin{tabular}{llll}
\hline Method & Applications & & \\
\cline { 2 - 4 } & Location & Property & Difficulty \\
\hline Tedesco & TS/P\&G & public & low \\
Swiss & TS/P\&G & public & low \\
French & TS/P\&G & public & low \\
Italian & TS/P\&G & public & low \\
CTLA & TS/P\&G/FA & public/private & low \\
Finnish & TS/P\&G & public & low \\
FEM & HT & public/private & high \\
ICONA & HT & public/private & high \\
Norma Granada & HT/P\&G & public/private & medium \\
STEM & TS/P\&G & public/private & medium \\
Contato & TS/P\&G/HT & public/private & medium \\
Removal & TS/P\&G & public/private & low \\
Maintenance & TS/P\&G & public/private & low \\
\hline
\end{tabular}

Notes: TS $=$ trees along the streets of town and cities; $P \& G=$ parks and gardens within city boundaries; FA = forests in urban areas around towns and cities with the purpose of providing amenities for the population; HT = special trees (individual trees may be considered important community resources because of unique or noteworthy characteristics or values) (Swiecki and Bernhardt 2001; Konijnendijk 2003; Konijnendijk et al. 2006)

tics or values (e.g., heritage, history, landmark, legacy, special interest, significant, or specimen trees). As regards the type of property in which the trees are located, a distinction is made between public and private spaces. Finally, three levels of difficulty are established with regard to the valuation procedure: low, medium, or high. These levels reflect the amount of data that needs to be collected and the complexity involved in obtaining it.

Fabbri (1989), Simpfendorfer (1979), and Caballer (1989; 1999 ) indicate that when valuing trees within the private sector, the system of evaluation by means of capitalization (adjusted to different interest rates according to the criteria adopted) is more widely accepted. City administrators may become embroiled in legal claims with individuals or legal entities who are sanctioned for damaging tree specimens, and if the amount of these sanctions is calculated by applying a parametric scale that is not clearly understood by the sanctioned party, there is a risk the sanction may be refused. For this reason, capitalization methods are the most commonly used in litigation for damages to public property. However, in assessing damages for disasters (e.g., hurricanes, fires), they are effective due to their low implementation difficulties. Of the two basic methods of capitalization, the maintenance method is preferable due to its lower data requirements (as it avoids the need to calculate both replacement and maintenance costs).

Parametric and multiplicative methods are better suited for the valuation of trees within the public sector, owing to their simplicity, speed, and efficiency. The Finnish and Swiss methods are equivalent, but the former takes into account a greater number of variables and gives a better idea of the size of the tree. CTLA and Tedesco are also very similar. The former has been applied since 1957 and has been revised on nine occasions, giving greater reliability. The CTLA method can be used in both the public and private sector due to its flexibility (Nowak et al. 2002).

The French and Italian methods are very similar, but differ in the price used to obtain the basic value (the former uses the replacement cost and the latter the nursery price). The Italian method is easier to implement due to the accessibility of the data used. ICONA and FEM are the best methods for the assessment of historic trees, as they include abundant information on each tree. However, the FEM approach is simpler to use, and as it is an additive integration method. FEM avoids increasing the differ- ences in valuation between appraisers. The Norma Granada and Contato methods can also be used in these valuations. One feature of both these methods is that they assess the health and aesthetic value of the tree (Table 4). The Norma Granada is a development of the ICONA method, although its third review has generated problems of implementation due to the lack of updated data. Jordi Chueca i Abancó (2012), a member of the committee for the third revision, maintains that it has been adversely affected by the lack of support from the Spanish Association of Parks and Gardens (AEPJP), which has failed to update the tables required for the assessments and has withdrawn them from its website, making it impossible to carry out a valuation at current market rates.

The most versatile methods are CTLA and Contato. They can be used in more locations than others and in any type of property with a medium or low degree of difficulty. CTLA is the best method for forests in urban areas or around towns and cities for the purpose of providing amenities for the population.

In conclusion, there are a number of methods with different types of application. The best method should be selected according to the primary objective, tree location, type of land ownership, and the availability of data. The methods with a higher degree of applicability are the CTLA, a simple parametric method, and the Contato method, a mixed method with medium difficulty. It is advisable to increase the efforts to objectify the correction index in the case of both parametric and mixed methods.

Acknowledgments. The writer's would like to thank Ms. Prudence Turner for the linguistic revision of the manuscript.

\section{LITERATURE CITED}

Abancó, Jordi. 2012. <www.drac.com/pers/chueca/>

AEPJP. 1990. Método para valoración de árboles y arbustos ornamentales: Norma Granada. Madrid: Asociación Española de Parques y Jardines Públicos.

AEPJP. 1999. Método para valoración de árboles y arbustos ornamentales: Norma Granada: revisión 1990. Madrid: Asociación Española de Parques y Jardines Públicos.

AEPJP. 2007. Método para valoración de árboles y arbustos ornamentales: Norma Granada: revisión 1999. Madrid: Asociación Española de Parques y Jardines Públicos.

Aldous, D.E. 2007. Social, environmental, economic, and health benefits of green spaces. In: Proceedings of the international symposium on horticultural plants in urban and peri-urban life. Acta Horticulturae 762:171-185.

Ayuga-Téllez, E., M.L. Contato Carol, C. González-García, M.A. Grande-Ortiz, and J. Velázquez. A new location index calculation method for use in urban tree appraisal applying multivariate data analysis. Journal of Urban Planning and Development (in press).

Barbier, E.B., and G.M. Heal. 2006. Valuing ecosystem services. The Economists' Voice 3(1):1-6.

Bartensa, J., S.D. Dayb, J.R. Harris, J.E. Doved, and T.M. Wynn. 2008. Can urban tree roots improve infiltration through compacted subsoils for stormwater management? Journal of Environmental Quality 37:2048-2057.

Becker, N., and S. Freeman. 2010. The economic value of old growth trees in Israel. Forest Policy and Economics 11:608-615.

Bergin, J., and C. Price. 1994. The travel cost method and landscape quality. Landscape Research 19(1):21-23.

Bernardini, C. 1958. Accertamento del piu probabile danno conseguente all'abbatimento di un platano secolare. Genio Rurale 3:1-8. 
Bernath, K., and A. Roschewitz. 2008. Recreational benefits of urban forests: Explaining visitors' willingness to pay in the context of the theory of planned behavior. Journal of Environmental Management 89(3):155-166.

Bernatzky, A. 1978. Tree Ecology and Preservation. Development in Agricultural and Management Forest Ecology, 2. New York: Elsevier Scientific Publishing Co.

Bratkovich, S. 2008. Municipal Forests Can Provide Useful Lumber Products Independent Sawmill and Woodlot Management pp. 28-32.

Bridgeman, P., M.J. Whitehead, and P.J. Jordan. 1979. Trees for town and country. London: David and Charles.

Bucur, V. 2006. Urban Forest Acoustics. USA: Springer.

Caballer V. 1989. Modelos para la valoración de plantas ornamentales. Invest Agrar: Econ 4(2):191-208.

Caballer, V. 1999. Valoración de árboles frutales, forestales medioambientales y ornamentales. Madrid: Ediciones Mundi-Prensa.

CAVAT. 2012. Capital Asset Value for Amenity Trees. The London Tree Officers' Association. <http://www.ltoa.org.uk/index. php?option=com_docman\&task=cat_view\&gid=98\&Itemid=140>

CEPAL. 1991. Impacto Ecológico de Contaminantes Atmosféricos. Comisión Económica para América Latina y el Caribe. Santiago de Chile, 1 a 3 de julio, pág. 8 .

Chadwick, L.C., and D. Neely. 1975. A guide to professional evaluation of landscape trees, specimen shrubs and evergreen. ISA (International Society of Arboriculture). Urbana II. 18 pp.

Chang, C., W.E. Hammitt, P. Chen, L. Machnik, and W. Su. 2008. Landscape and Urban Planning 85(2):79-84.

Chen, W.Y., and C.Y. Jim. 2008. Cost-benefit analysis of the urban greening project in a new Chinese city. Cities 25:298-309.

Choumert, J., and J. Salanié. 2008. Provision of urban green spaces: Some insights from economics. Landscape Research 33(3):331-345.

Codina R., and J. Barón. 2003. Criterio ambiental volumétrico para cálculo de espacios verdes. Revista de la Facultad de Ciencias Agrarias de la Universidad Nacional de Cuyo (J FCA UNCuyo). Tomo 35(1):11-24.

Coley, R.L. 1997. Where Does Community Grow? Environment and Behavior 29(4):468-494.

Contato-Carol M.L. 2004. Análisis estadístico multivariante del arbolado urbano de Santiago del Estero (Argentina) y estimación de su valor mediante modelos econométricos. Doctoral thesis. Polytechnic University of Madrid, Spain. 278 pp.

Contato-Carol, M.L., E. Ayuga-Téllez, and M.A. Grande-Ortiz. 2008. A comparative analysis of methods for the valuation of urban trees in Santiago del Estero, Argentina. SJAR 6(3):341-352.

CTLA. 1992. Guide for Plant Appraisal, 8th Edition. Council of Tree and Landscape Appraisers. ISA, Savoy, IL, USA. 103 pp.

CTLA. 2000. Guide for Plant Appraisal, 9th Edition. Council of Tree and Landscape Appraisers. ISA, Savoy, IL, USA. 143 pp.

De Groot, R., M. Wilson, and R. Boumans. 2002. A typology for the description: Classification and valuation of ecosystem functions, goods and services. In: The Dynamics and Value of Ecosystem Services: Integrating Economic and Ecological Perspectives. Special Issue of Ecological Economics 41(3):367-567.

Delang, C.O., and T.Y. Ling. 2008. Managing wetlands: an ecological economic analysis of the Hong Kong Wetland Park. Ecological Economy 4:440-453.

Dombrow, J., M. Rodriguez, and C.F. Sirmans. 2000. The market value of mature trees in single-family housing markets. The Appraisal Journal 68:39-43.
Donovan, G.H., and D.T. Butry. 2009. The value of shade: Estimating the effect of urban trees on summertime electricity use. Energy and Buildings 41:662-668.

Donovan, G.H., and D.T. Butry. 2008. Market-based approaches to tree valuation. Arborist News 17(4):52-55.

Dwyer, J.F. 1995. The Role Economics Can Play as an Analytical Tool in Urban Forestry. In: G.A. Bradley (Ed.). Urban Forest Landscapes. Integrating Multidisciplinary Perspectives. Seattle, University of Washington Press. pp. 88-99.

Dwyer, J.F. 1995. The Significance of Trees and Their Management in Built Environments. On Proceedings of an International Workshop on Trees and Buildings, Lisle, IL, May 31-June 2. pp. 3-11.

Dwyer, J.F., E.G. McPherson, H.W. Schroeder, and R.A. Rowntree. 1992. Assessing the benefits and costs of the urban forest. Journal of Arboriculture 18(5):227-234.

Dwyer, J.F., G.L. Peterson, and A.J. Darragh. 1983. Estimating the value of urban forests using the travel cost method. Journal of Arboriculture 9:182-185.

Dwyer, J.F., D.J. Nowak, M.H. Noble, and S.M. Sisinni. 2000. Connecting people with ecosystems and the 21 st century: an assessment of our nation's urban forests. Gen. Tech. Rep. 490. Portland, OR: U.S. Dept. of Agriculture, Forest Service, Pacific Northwest Research Station.

Espluga González de la Peña, A.P. 1989. Valoración de árboles ornamentales: modelo para la determinación de un valor básico en función del tamaño. Doctoral thesis. Polytechnic University of Madrid, Spain. 137 pp. [in Spanish]

Fabbri, M. 1989. Metodi di stima del valore delle piante ornamentali. Acer 2:15-19. [in Italian]

Fang, C.F., and D.L. Ling. 2003. Investigation of the noise reduction provided by tree belts. Landscape and Urban Planning 63:187-195.

Ferraris, P. 1984. Note sulla valutaziones del soprasuolo arbóreo di parchi e giardini. J Flortécnica November 11-15. [in Italian]

Frumkin, H., 2003. Healthy places: Exploring the evidence. American Journal of Public Health 93(9):1451-1456

Garrod, G.D., and K.G. Willis. 1997. The non-use benefits of enhancing forest biodiversity: A contingent ranking study. Ecological Economics 21:45-61.

Gundersen, V., L.H. Frivoldb, T. Mykinga, B.H. Øyen. 2006. Management of urban recreational woodlands: The case of Norway. Urban Forestry \& Urban Greening 5:73-82.

Heal, G.M. 2007. A Celebration of Environmental and Resource Economics. Review of Environmental Economics and Policy 1(1):7-25.

Heisler, G.M., and R.H. Grant. 2000. Ultraviolet radiation in urban ecosystems with consideration of effects on human health. Urban Ecosystems 4:193-229.

Huang, J., R. Ritschard, N. Sampson, and H. Taha. 1992. Cooling Our Communities: A Guidebook on Tree Planting and Light-Colored Surfacing. EPA: Policy, Planning and Evaluation (PM-221).

Huang, J., H. Akbary, H. Taha, and A. Rosenfeld. 1987. The potential of vegetation in reducing summer cooling loads in residential buildings. Journal of Climate and Applied Meteorology 26:1103-1106.

Hull, R.B., IV. 1992a. How the public values urban forests. Journal of Arboriculture 18(2):98-101.

Hull, R.B., IV. 1992b. Brief Encounters with Urban Forests Produce Moods that Matter. Journal of Arboriculture 18(6):322-324.

Iamtrakul, P., K. Hokao, and K. Teknomo. 2005. Public park valuation using travel cost method. Proceedings of the Eastern Asia Society for Transportation Studies. 5:1249-1264. 
Jim, C.Y., and W.Y. Chen. 2006a. Recreation-amenity use and contingent valuation of urban green spaces in Guangzhou, China. Landscape and Urban Planning 75(1-2):81-96.

Jim, C.Y., and W.Y. Chen. 2006b. Impacts of urban environmental elements on residential housing prices in Guangzhou, China. Landscape and Urban Planning 78(4):422-434.

Jim, C.Y., and W.Y. Chen. 2009. Ecosystem services and valuation of urban forests in China. Cities 26(4):187-194.

Jim, C.Y. 2003. Protection of urban trees from trenching damage in compact city environments. Cities 20(2):87-94.

Jim, C.Y. 2006. Formulaic expert method to integrate evaluation and valuation of heritage trees in compact city. Environmental Monitoring and Assessment 116:53-80

Jo, H. 2001. Impacts of urban greenspace on offsetting carbon emissions for middle Korea. Journal of Environmental Management 64:115-126.

Joye, Y., K. Willems, M. Brengman, and K. Wolf. 2010. The Effects of urban retail greenery on consumer experience: Reviewing the evidence from a restorative perspective. Urban Forestry \& Urban Greening 9(1):57-64.

Kaplan, R., and S. Kaplan. 1989. The experience of nature: A Psychological Perspective. New York: Cambridge University Press. 360 pp.

Kaplan, S., and R. Kaplan. 2009. Creating a larger role for environmental psychology: The reasonable person model as an integrative framework. Journal of Environmental Psychology 29(3):329-339.

Kaplan, S. 1995a. The urban forest as a source of psychological wellbeing. In: G.A. Bradley (Ed.). Urban forest landscapes: Integrating multidisciplinary perspectives. Seattle: University of Washington Press. pp. 101-108.

Kaplan, S. 1995b. The restorative benefits of nature: Toward and integrated framework. Journal of Environmental Psychology 15(3):169-182.

Kirnbauera, M.C., W.A. Kenneyb, C.J. Churchillc, and B.W. Baetz. 2009. A prototype decision support system for sustainable urban tree planting programs. Urban Forestry \& Urban Greening 8(1):3-19.

Kjelgren, R., and T. Montague. 1998. Urban tree transpiration over turf and asphalt surfaces Atmospheric Environment 32(1):35-41.

Konijnendijk, C.C. 2003. A decade of urban forestry in Europe. forest policy and economics. 5(3):173-186.

Konijnendijk, C.C., R.M. Ricard, A. Kenney, and T.B. Randrup. 2006. Defining urban forestry - A comparative perspective of North America and Europe. Urban Forestry \& Urban Greening 4(3-4):93103.

Kuo, F.E., and Sullivan, W.C., 2001. Environment and Crime in the Inner City. Environment and Behavior 33(3):343-367.

Kweon, B., W.C. Sullivan, and A.R. Wiley. 1998. Green common spaces and the social integration of inner-city older adults. Environment and Behavior 30(6):832-858.

Lafortezza, R., G. Carrus, and G. Sanesi. 2009. Benefits and well-being perceived by people visiting green spaces in periods of heat stress. Urban Forestry \& Urban Greening 8(2):97-108.

Laverne, R.J., and K. Winson-Geideman. 2003. The influence of trees and landscaping on rental rates at office buildings. Journal of Arboriculture 29(5):281-290.

Lewis, R.K. 1997. Urban Trees: Serving the Eye, Environment, Pocketbook, and Psyche. American Forest 103(2):22-25.

Lo, A.Y., and C.Y. Jim. 2010. Willingness of residents to pay and motives for conservation of urban green spaces in the compact city of Hong Kong. Urban Forestry \& Urban Greening 9(2):113-120.

López Arce, M.A. 1975. El cálculo de indemnizaciones derivadas de la pérdida de árboles ornamentales. ICONA, Ministerio de Agricultura, Madrid. 19 pp. [in Spanish]
Luttik, J. 2000. The Value of Trees, Water and Open Space as Reflected by House Prices in the Netherlands. Landscape and Urban Planning 48:161-167.

McComb, G., V. Lantz, K. Nash, R. Rittmaster. 2006. International valuation databases: Overview, methods and operational issues. Ecological Economics 60:461-472.

McFarland, K. 1994. Community Forestry and Urban Growth: A Toolbox for Incorporating Urban Forestry Elements into Community Plans. Washington State Department of Natural Resources, December 1994.

McKean, J.R., D.M. Johnson, R.G. Walsh. 1995. Valuing time in travel cost demand analysis: An empirical investigation. Land Economics 71:96-105.

McPherson, E.G., J.R. Simpson, P.J. Pepper, Q. Xiao. 1999b. Benefitcost analysis of Modesto's municipal urban forest. Journal of Arboriculture 25:235-248.

McPherson, E.G., J.R. Simpson. 1999a. Carbon dioxide reduction through urban forestry. Guidelines for professional and volunteer tree planters. Gen. Tech. Rep. PSW-GTR-171. Albany, CA: Pacific Southwest Research Station, Forest Service U.S. Department of Agriculture. $237 \mathrm{pp}$.

McPherson, E.G., and J. Muchnick. 2005. Effects of street tree shade on asphalt concrete pavement performance. Journal of Arboriculture 31(6):303-310

McPherson, E.G., and R.A. Rowntree. 1993. Energy conservation potential of urban tree planting. Journal of Arboriculture 19(6):321-331.

McPherson, E.G. 1995. Net Benefits of Healthy and Productive Urban Forests. Urban Forest Landscapes: Integrating Multidisciplinary Perspectives. G.A. Bradley (Ed.). University of Washington Press: Seattle \& London. 180 pp.

McPherson, E.G., J. Simpson, P. Peper, S. Maco, and Q. Xiao. 2005. Municipal forest benefits and costs in five U.S. cities. Journal of Forestry 103(8):411-416.

Miller, R.W. 1997. Urban forestry: Planning and managing urban greenspaces. 2nd edition. Prentice Hall, New Jersey.

Montague, T., and R. Kjelgren. 2004. Energy balance of six common landscape surfaces and the influence of surface properties on gas exchange of four containerized tree species. Scientia Horticulturae 100(1-4):229-249.

Morales, D.J. 1980. The contribution of trees to residential property value. Journal of Arboriculture 6(11):305-308.

Morancho, A.B. 2003. A hedonic valuation of urban green areas, Landscape and Urban Planning 66(1):35-41.

More, T.A., T. Stevens, and P.G. Allen. 1988. Valuation of urban parks. Landscape and Urban Planning 15:139-152.

Moretón, J. 1996. Contaminación del aire en la Argentina. Universo. Buenos Aires. 125 pp.

Morey, E.R., W.D. Shaw, and R.D. Rowe. 1991.Adiscrete choice model of recreational participation, site choice, and activity valuation when complete trip data are not available. Journal of Environmental Economics and Management 20:181-201.

Neilan, C. 2008. CAVAT: Capital asset value for amenity trees. Revised edition. London Tree Officers Association.

Nowak, D.J., and D.E. Crane. 2002. Carbon storage and sequestration by urban trees in the USA. Journal of Environmental Pollution 116(3):381-389.

Nowak, D.J., D.E. Crane, and J.F. Dwyer. 2002. Compensatory values of urban trees in the U.S. Journal of Arboriculture 28(4):194-199.

Nowak, D.J., D.E. Crane, and J.C. Stevens. 2006a. Air pollution removal by urban trees and shrubs in the United States. Urban Forestry \& Urban Greening 4(3-4):115-123. 
Nowak, D.J., R.E. Hoehn III, D.E. Crane, J.C. Stevens, J.T. Walton. 2006b. Assessing urban forest effects and values, Washington, D.C.'s urban forest. Assessing urban forest effects and values, Washington, D.C.'s urban forest. Resour. Bull. NRS-1. Newtown Square, PA, U.S. Department of Agriculture, Forest Service, Northern Research Station. 24 p.

Nowak, D.J., E.G. McPherson. 1993. Cuantificación ambiental de los árboles en Chicago. UNASYLVA 44(7):39-44.

Nowak, R.S., D.S. Ellsworth, S.D. Smith. 2004. Functional responses of plants to elevated atmospheric $\mathrm{CO}_{2}$ - do photosynthetic and productivity data from FACE experiments support early predictions? Journal of New Phytologist 162:253-280.

O'Brien, L. 2005. Trees and woodlands: Nature's health service. Farnham, UK, Forest Research. 48 pp.

Oke, T.R., 1980. Climatic impacts of urbanization. In: W. Bach, J. Pank-Rath, and J. Williams (Eds.). Interactions of energy and climate. Proc. Internat. Workshop Münster, Germany. pp. 339-361. Reidel publ. Dordrecht.

Oke, T.R. 1989. The micrometeorology of the urban forest. Phil. Trans. R. Soc. Lond. 324, 335-349.

Parsons, G. 2003. The travel cost model. pp. 269-330. In: P.A. Champ et al. (Eds.). A premier on non-market valuation. Dordrecht, Netherland: Kluwer Academic Publisher.

Pesson, P. 1978. Ecología Forestal. El bosque: clima, suelo, árboles, fauna. Mundiprensa (Ed.). Madrid, España. 389 pp.

Ponce-Donoso, M., L. Moya, and O. Bustos-Letelier. 2009. Evaluation of formulas for the appraisal of urban trees in municipalities of Chile. Sci. For. Piracicaba. 37(83):321-329.

Powe, N.A., and K.G. Willis. 2002. Mortality and morbidity benefits of air pollution absorption by woodland. Report to Forestry Commission, Edinburgh. December 2002.

Powell, K. 1993. Conserving Energy with Plants. North Carolina Cooperative Extension Service, Leaflet \#621.

Price, C. 2003. Quantifying the aesthetic benefits of urban forestry. Urban Forestry \& Urban Greening 1:123-133.

Sander, H., S. Polasky, and R.G. Haight. 2010. The value of urban tree cover: A hedonic property price model in Ramsey and Dakota Counties, Minnesota, USA. Ecological Economics 69:1646-1656.

Schmied, A., and W. Pillmann. 2003. Tree protection legislation in European cities. Urban Forestry \& Urban Greening 2(2):115-124.

Schulze, W.D., D.S. Brookshire, E.G. Walther, K.K. McFarland, M.A. Thayer, R.L. Whitworth, S. Ben-David, W. Malm, and J. Molenar. 1983. The economic benefits of preserving visibility in the National Parklands of the Southwest. Natural Resource Journal 23:149-173.

Sherrill, S., 2003. Harvesting Urban Timber. Linden Publishing, Fresno, CA. 224 pp.

Simpfendorfer, K.J. 1979. Some thoughts on tree valuation. Journal of Australian Parks and Recreation Ag. 20-22.

Smith, W.H., 1990. Air Pollution and Forests: Interactions Between Air Contaminants and Forest Ecosystems. Springer Verlag, Berlin. 512 pp.

Sugiyama, T., E. Leslie, and B. Giles-Corti. 2008. Associations of neighbourhood greenness with physical and mental health: Do walking, social coherence and local social interaction explain the relationships? Journal of Epidemiology and Community Health 62(5): e9.

Swiecki, T.J., and E.A. Bernhardt. 2001. Guidelines for Developing and Evaluating Tree Ordinances. <http://phytosphere.com/treeord/index. $\mathrm{htm}>$

Taylor, A.F., F. Kuo, and W. Sullivan. 2001. Coping with ADD: The Surprising Connection to Green Play Settings. Environment and Behavior 33(1):54-77.
Troy, A., and J.M. Grove. 2008. Property values, parks, and crime: A hedonic analysis in Baltimore, MD. Landscape and Urban Planning. 87(3):233-245.

Tyrväinen, L., and A. Miettinen. 2000. Property prices and urban forest amenities. Journal of. Environal Economics and Management 39:205-223.

Tyrväinen, L. 1997. The amenity value of the urban forest: an application of the hedonic pricing method. Landscape and Urban Planning 37:211-222.

UEA. 2009. Urban Ecosystem Analysis. Summaries of American Forests' Urban Ecosystem Analyses. American Forests. Accessed 03/10/2010. <www.americanforests.org/resources/urbanforests/analysis.php>

Ulrich, R.S. 1981. Natural Versus Urban Scenes, Some Psycho-physiological Effects. Environment and Behavior 13(5):523-556.

Ulrich, R.S. 1984. View through a window may influence recovery from surgery. Science 224:420-421.

Ulrich, R.S. 1986. Human responses to vegetation and landscapes. Landscape and Urban Planning 13:29-44.

Vesely, E.T. 2007. Green for green: The perceived value of a quantitative change in the urban tree estate of New Zealand. Ecological Economics 63(2-3):605-615.

Watson, G. 2002. Comparing formula methods of tree appraisal. Journal of Arboriculture 28(1):11-18.

Willis, K.G., and G.D. Garrod. 1991. An individual travel cost method of evaluating forest recreation. Journal of Agricultural Economics 42:33-42.

Wolf, K.L. 2004. Nature in the retail environment: Comparing consumer and business response to urban forest conditions. Landscape Journal 23(1):40-51.

Wolf, K.L. 2005. Trees in the small city retail business district: comparing resident and visitor perceptions. Journal of Forestry 103(8):390-395.

Wolf, K.L. 2007. City trees and property values. Arborist News 16:34-36.

Wolf, K.L. 2009a. Strip malls, city trees, and community values. Arboriculture \& Urban Forestry 35(1):33-40.

Wolf, K.L. 2009b.Trees mean business: city trees and the retail streetscape. Main Street News 263:1-9.

Xu, Z., G. Cheng, Z. Zhang, Z. Su, and J. Loomis. 2003. Applying contingent valuation in China to measure the total economic value of restoring ecosystem services in Ejina region. Ecological Economics 44:345-358.

Zawacki, W.T., A. Marsinko, and J.M. Bowker. 2000. A travel cost analysis of nonconsumptive wildlife-associated recreation in the United States. Forest Science 46(4):496-506.

Zhang, Y., A. Hussain, J. Deng, and N. Letson. 2007. Public Attitudes Toward Urban Trees and Supporting Urban Tree Programs. Environment and Behavior 39(6):797-814.

Zhu, P., and Y. Zhang. 2008. Demand for urban forests in United States cities. Landscape and Urban Planning 84:293-300. 
M.A. Grande-Ortiz (corresponding author)

ETSI de Montes

Universidad Politécnica de Madrid

Ciudad Universitaria s/n. 28040 Madrid, Spain

m.angeles.grande@upm.es

E. Ayuga-Téllez.

ETSI de Montes

Universidad Politécnica de Madrid

Ciudad Universitaria s/n. 28040 Madrid, Spain

M.L. Contato-Carol

Facultad de Ciencias Forestales

Universidad Nacional de Santiago del Estero

Argentina

Zusammenfassung. Stadtbäume leisten eine Anzahl von grundsätzlichen Funktionen in Verbindung mit der Umwelt und der Wohlfahrtswirkung auf die Bewohner einer Stadt (ökologisch, freizeittechnisch, psychologisch), obwohl diese Vorteile nicht so leicht zu quantifizieren sind. Dennoch gibt es einige Situationen, in denen es von Vorteil ist, den Bäumen einen ökonomischen Wert beizumessen. Es gibt gegenwärtig verschiedene Methoden zur Wertschätzung der Vorteile von Bäumen und Grünräumen in Siedlungsgebieten, einschließlich statistische Methoden, Reisekosten-Methode, Kontingent-Bewertung, Marktpreismethode und integrierte Methoden. Dennoch werden diese Methoden nicht bei der offiziellen Bewertung von Bäumen verwendet, in diesen Fällen bedient man sich Methoden der Wertermittlung durch Abschätzung. Das Ziel dieser Untersuchung war, die verschiedenen Methoden der Wertermittlung in ihren spezifischen Eigenschaften zu studieren und ihre Einsatzmöglichkeiten zu erfassen. Das Hauptergebnis unserer Untersuchung ist, dass es ein Vielzahl an Methoden gibt, die unterschiedliche Anwendungsbereiche finden. Die beste Methode wird ausgewählt nach dem Baumstandort, der Landnutzung durch den Eigentümer und der Verfügbarkeit von Daten. Methoden mit einem höheren Grad an Einsatzmöglichkeit sind: CTLA, eine parametrische Methode mit niedrigem Schwierigkeitsgrad und Contato, eine gemischte Methode mit mittlerem Schwierigkeitsgrad. In jedem Fall ist es ratsam, die Anstrengungen zur Objektivierung des Korrektur-Indexes im Falls der parametrischen und gemischten Methoden zu steigern.

Resumen. Los árboles urbanos realizan una serie de funciones básicas relacionadas con el medio ambiente y el bienestar de los habitantes de las ciudades (ecológicas, recreativas, psicológicas), aunque sus beneficios no son fácilmente cuantificables. Sin embargo, en ciertas situaciones, es esencial para asignar un valor económico a los árboles. Actualmente existen varios métodos para valorar los beneficios de los árboles y espacios verdes en los asentamientos humanos, incluidos los métodos estadísticos, el método de costo de viaje, valoración contingente, método de precios hedónico y métodos integrados. Sin embargo, estos métodos no se usan en tasaciones oficiales de árboles urbanos; en estos casos, se utilizan métodos de evaluación. El objetivo de este trabajo es estudiar los métodos de evaluación utilizados por sus características detalladas y las posibilidades de su aplicación. La principal conclusión de esta revisión es que hay una serie de métodos con diferentes tipos de aplicación. El mejor método es seleccionado de acuerdo a la ubicación del árbol, tipo de propiedad de la tierra y la disponibilidad de datos. Los métodos con un mayor grado de aplicabilidad son CTLA, un método paramétrico de dificultad baja y Contato, un método mixto de dificultad media. En cualquier caso, es aconsejable aumentar esfuerzos para hacer objetivo el índice de corrección en el caso de métodos paramétricos y mixtos. 